\title{
Occurrence of Escherichia coli and Escherichia Coli 0157:H7 in cattle, farm environment, milk and beef
}

\author{
Mian Khaqan Shah*, Saleha Abdul Aziz and Zunita Zakaria \\ ${ }^{1}$ Faculty of Veterinary Medicine, Universiti Putra Malaysia, 43400 UPM Serdang, Malaysia \\ Email: khaqan.vet@gmail.com
}

Received 2 August 2017; Received in revised form 14 September 2017; Accepted 11 October 2017

\begin{abstract}
Aims: The aim of this study was to determine the occurrence of Escherichia coli and E. coli O157:H7 in the cattle, farm environment beef and milk samples.

Methodology and results: A total of 192 samples were collected from cattle (rectal faeces) (96) and their farm environment (96) including feed, floor of stall swabs, pooled flies and water samples and 30 milk samples from dairy cattle. A total of seven markets were selected to collect 60 beef samples. The presence of $E$. coli and E. coli $\mathrm{O} 157: \mathrm{H} 7$ was determined using culture method and confirmed using PCR assay. The overall occurrence rate of $E$. coli in the farm was $49 \%$. In milk, the occurrence of $E$. coli was $33.3 \%$ and in beef was $10 \%$. The isolated $E$. coli were then screened for E. coli $\mathrm{O} 157$ using latex agglutination test (Oxoid) and $34.2 \%$ were found positive to the test. The identified E. coli O157 isolates were then subjected to multiplex PCR with five primer pairs. They were all negative except for $3.6 \%$ of the $E$. coli $\mathrm{O} 157(10.5 \%)$ isolates which were positive for the presence of $\mathrm{fliCH} 7$ genes.

Conclusion, significance and impact of study: This study showed the absence of $E$. coli $0157: \mathrm{H} 7$ in the cattle, farm environment, milk and beef. This study may provide a base for conducting a broader spectrum study by having more risk factors included in the study of $E$. coli in cattle in Malaysia. Further detailed studies may provide a platform to control emergence and distribution of pathogenic bacteria and ensure good control and surveillance strategies and policies.
\end{abstract}

Keywords: E. coli O157, cattle, environment, milk, beef

\section{INTRODUCTION}

Food borne illness is an unavoidable and is of great public health concern worldwide due to consumption of contaminated raw and uncooked food (Jianghong Meng, 2007). Most pathogens cause infection while a number produce toxins inside the host after ingestion which may lead to mild to severe diarrhea and even death in severe infection. There are two types of E. coli, pathogenic and non-pathogenic $E$. coli. The non-pathogenic strains of $E$. coli are present in the normal intestinal microflora which are harmless, hinder the growth of harmful bacteria, produce vitamins and are described as commensal E. col (Nataro and Kaper, 1998; Beauchamp and Sofos, 2010). Based on the pathogenicity of the disease and presence of virulence factors, at least seven pathotypes of pathogenic E. coli also known as diarrheagenic E. coli have been identified and studied, namely, enterotoxigenic E. coli (ETEC), enterohaemorrhagic E. coli (EHEC), enteropathogenic E. coli (EPEC), enteroinvasive E. coli (EIEC); including Shigella, enteroaggregative E. coli (EAEC), diffusely adherent E. coli (DAEC) (Beauchamp and Sofos, 2010; Jafari, et al., 2012; Allocati et al., 2013) and the recently emerged, adherent invasive $E$. coli
(AIEC) (Allocati et al., 2013; Martinez-Medina and GarciaGil, 2014).

Of all diarrheagenic $E$. coli identified, Shiga-toxin or Vero toxin producing (STEC/VTEC) $E$. coli is the most significant pathotype in human diseases (Wani et al., 2003). There are many serotypes in STEC and among them, the EHEC serotype O157:H7 are found to be highly virulent, responsible for outbreaks of bloody diarrhea and hemolytic uremic syndrome (HUS) worldwide. Ruminants are found to be the natural reservoir hosts for these organisms (Nataro \& Kaper, 1998). STEC was first recognized as a human pathogen in 1982 (Riley et al., 1983). In animals, STEC is found in the intestines of newborn animals. However the healthy adult animals act as subclinical carriers for STEC and considered as the common source of 0157 serotype in humans worldwide (Wani et al., 2003).

For identification of different pathotypes of E. coli, polymerase chain reaction (PCR) method is used and is based on amplification of specific virulent genes (Nataro and Kaper, 1998). Watterworth et al. (2005) designed a multiplex PCR assay by using six sets of primers to identify four different pathotypes. Chang et al. (2013) 
designed a duplex PCR assay by using two sets of primers for the detection of E. coli O157: $\mathrm{H} 7$.

In Malaysia, limited studies were reported on the occurrence of pathogenic $E$. coli in cattle, farm environment, milk and beef. The presence of $E$. coli 0157:H7 may possibly be due to a number of factors such as farm husbandry practices and environment differences. Therefore, the aim of this study was to determine the occurrence of $E$. coli $\mathrm{O} 157: \mathrm{H} 7$ in cattle, the farm environment, milk and beef.

\section{MATERIALS AND METHODS}

\section{Sample collection}

A total of eight cattle farms were visited. Faecal samples from twelve cattle in each farm were directly collected from the rectum using sterile gloves. Three of each type of environmental samples were collected from all farms which comprised feed, pooled flies of five flies per pooled sample, swabs of floor of stalls and water. Six milk samples each from five dairy cattle farms were directly collected from the teats of each dairy cattle. Sixty beef samples were purchased from seven wet markets. Each of the sample collected was kept in individual sterile plastic bag and put in a cool box with ice packs. The samples were transported to the Veterinary Public Health Laboratory, UPM and processed within $3 \mathrm{~h}$ following collection.

\section{Treatment of samples}

All of the samples except milk samples were individually placed in buffered peptone water (BPW) (Oxoid) and incubated at $37{ }^{\circ} \mathrm{C}$ aerobically for $24 \mathrm{~h}$ while each of the milk samples was placed in trypton soy broth (TSB) (Oxoid) and incubated as above. The culture of water samples was according to Wong et al. (2007). Each 100 $\mathrm{mL}$ of water sample was filtered using a sterile cellulose nitrate membrane filter of $47 \mathrm{~mm}$ diameter with $0.45 \mu \mathrm{m}$ pore-size (Milipore, Sartorius Stedim, Biotech, Goettingen. Germany). Then the membrane filter was put in a sterile bottle containing $100 \mathrm{~mL}$ BPW (Oxoid) and incubated at $37^{\circ} \mathrm{C}$ aerobically for $24 \mathrm{~h}$. For beef samples, novobiocin $(20 \mathrm{ug} / \mathrm{mL}$ ) was added to TSB (Oxoid) in sterile stomacher bags and homogenized for $1.5 \mathrm{~min}$ in a stomacher. The homogenate was then incubated for $6 \mathrm{~h}$ at $37^{\circ} \mathrm{C}$, then 1 $\mathrm{mL}$ of this incubated mixture was added to $10 \mathrm{~mL}$ TSB (Oxoid) and incubated for $2 \mathrm{~h}$ at $37^{\circ} \mathrm{C}$.

\section{Immunomagnetic separation}

Each of the incubated cultures was subjected to immunomagnetic separation (IMS) with Dynabeads $\AA$ antiE. coli 0157 according to the manufacturer's instructions (Dynal, Oslo, Norway). For qualitative analysis of E. coli O157, direct plating is frequently practised and the use of immunomagnetic separation (IMS) technique is reported to improve their isolation because the IMS technique performed more sensitive detection of specific microorganism in comparison with direct plating (Šafařiková and Šafařik, 2001). The beads were washed according to Cooley et al. (2007).

\section{Isolation and identification}

The bead bacteria complex obtained from IMS of each faeces, feed, flies, floor of stall swabs, water, milk and beef samples was inoculated on Sorbitol MacConkey agar (Oxoid-Thermo) supplemented with Cefixime Tollurite (CT-SMAC) to obtain colourless non-sorbitol fermenting colonies. The same beads obtained from IMS were also inoculated on CHROMagar O157 to obtain pink/mauve colour colonies due to the presence of chromogenic substrates in the medium (CHROMagar ${ }^{\mathrm{TM}}$ ) and both were incubated aerobically at $37{ }^{\circ} \mathrm{C}$ for $18-24 \mathrm{~h}$. These presumptive colonies were picked and sub-cultured onto nutrient agar (Oxoid) and incubated at $37{ }^{\circ} \mathrm{C}$ for $24 \mathrm{~h}$ (Khanjar and Alwan, 2014). A total of 5 typical colonies based on manufacturer's instruction were obtained from Sorbitol MacConkey agar (Oxoid-Thermo) supplemented with Cefixime Tollurite (CT-SMAC) and CHROMagar 0157 for biochemical tests. The presumptive colonies were subjected to gram staining and biochemical tests which were indole, methyl red, Voges-Proskauer and citrate utilization tests which are common tests for the identification of $E$. coli (Quinn et al., 2002). Out of 5 selected colonies, even if a single colony appeared positive then the sample was considered positive. The $E$. coli isolates were kept on nutrient agar slants (Oxoid) at room temperature until used.

\section{Detection of $E$. coli 0157 isolates by latex agglutination test}

Latex agglutination test (DrySpot E. coli O157; Oxoid) was used for identification of $E$. coliO157 serogroup among presumptive $E$. coli isolates. The blue dried particles on the test cards are representing reactive (positive) and non-reactive (negative) antibodies. The identification of $E$. coli $\mathrm{O} 157$ is presumed positive when agglutination appears in the reactive blue particles and no agglutination appears in the non-reactive particles on the test cards when $E$. coli isolates are mixed with the particles. If no agglutination appears on the test and control blue particles then the test for $E$. coli $\mathrm{O} 157$ is considered negative.

\section{Polymerase chain reaction (PCR) assay}

Conventional boiling method was used for the DNA extraction of the isolates using sterile distilled water. A loop full of colonies was taken and added to $1000 \mu \mathrm{L}$ sterile distilled water in a $1.5 \mathrm{~mL}$ Eppendorf tube. The suspension was incubated at $94{ }^{\circ} \mathrm{C}$ for $10-15 \mathrm{~min}$ in dry water bath and allowed to cool down to room temperature. The suspension was then centrifuged for $3 \mathrm{~min}$ at 13,000 $\mathrm{rpm}$. The supernatant from each centrifuge tube was collected in a new $1.5 \mathrm{~mL}$ Eppendorf tube. The 
supernatant was used as template DNA and the pellets were discarded.

The DNA was amplified in a total $50 \mu \mathrm{L}$ reaction volume comprised $25 \mu \mathrm{L}$ of Master Mix (BIOLINE), $5 \mu \mathrm{L}$ $(10 \mathrm{mM})$ of primer set as described by Watterworth et al. (2005) and Chang et al. (2013), using the internal control targeted genes st, It, lal, rfbO157 and fliCH7 (Table 1), 4 $\mu \mathrm{L}$ of template DNA and $16 \mu \mathrm{L}$ of deionized distilled water. The total volume of the mixture was $50 \mu \mathrm{L}$ which was adjusted with deionized distilled water. The final reaction mixture was then amplified in DNA thermal cycler (Eppendorf) with the following m-PCR protocols: an initial denaturation step at $95^{\circ} \mathrm{C}$ for $5 \mathrm{~min}$, followed by 30 cycles of denaturation at $94^{\circ} \mathrm{C}$ for $1 \mathrm{~min}$, annealing at $55^{\circ} \mathrm{C}$ for 1 min and extension at $72{ }^{\circ} \mathrm{C}$ for $1 \mathrm{~min}$, ending with a final extension at $72^{\circ} \mathrm{C}$ for $10 \mathrm{~min}$.

The PCR reaction mixture was visualized by gel electrophoresis through $2 \%(\mathrm{w} / \mathrm{v})$ (Promega, USA) agarose (which contained Tris-Borate-EDTA (TBE) solution (89 mM Tris Base, $89 \mathrm{mM}$ Boric acid, $2 \mathrm{mM}$ EDTA, pH 8.3) in $0.5 \times$ TBE buffer solution at 80 volts for $70 \mathrm{~min}$. The gel was then stained with ethidium bromide for $10 \mathrm{~min}$ followed by de-staining with distilled water for 30 min. The gel was then viewed under UV transilluminator by the aid of Alpha Imager (Bio-Rad). A DNA-molecular ladder (100-bp ladder) (Vivantis Technologies) was included in each gel.

\section{RESULTS AND DISCUSSION}

Escherichia coli is said to be highly adaptable to various types of environments and colonize wide range of mammals as well as birds (Beauchamp and Sofos, 2010). Due to their invasiveness in penetrating the mucosal surfaces some strains of $E$. coli are considered to be pathogenic strains, as they can cause a variety of illnesses in humans (Nataro and Kaper, 1998; Beauchamp and Sofos, 2010; Croxen and Finlay, 2010).

In this study, a total of 192 samples which consisted of 96 faeces, 24 feeds, 24 pooled flies, 24 floor of stall swabs and 24 water samples were collected from eight dairy and beef cattle farms. Based on biochemical tests, $49 \%$ (95/192) were positive for E. coli. The occurrence of $E$. coli in cattle and farm environment in each cattle farm is presented in Table 2 .

In the present study, E. coli were found in faeces (cattle) at $55 \%$ which was similar to a study by Awadallah et al. (2013) in Egypt at $48 \%$. These findings were also similar to a study by Hossain et al. (2014) in Bangladesh in which $49 \%$ E. coli were observed among faecal samples of calves. The works of Fluckey et al., (2007) on faeces (cattle) at abattoirs in United States found $E$. coli ranged from 98 to $55 \%$. High prevalence was also observed in a study by Mainda et al. (2015) among faeces (cattle) in Zambia at $98.7 \%$.

Previous studies had reported several risk factors associated with the colonization of $E$. coli in cattle including feed, manure, flies, water, direct contact with the infected animal and animal wastes, which contributed to the occurrence and re-occurrence of infection and contamination of the animals and farm with $E$. coli (Jiang et al., 2002; Dodd et al., 2003). Contaminated water can also serve as an important mode of spread of $E$. coli within a farm (Jiang et al., 2002). In the present study, a total of $43.7 \%$ farm environmental samples, including $41.6 \%$ of water samples and $62.5 \%$ of the floor of stalls were contaminated with $E$. coli. Almost similar results were reported in a study by Adzitey et al. (2010), in which occurrence of $E$. coli in soil was $72 \%$ and in wash water was $50 \%$. A total of $37.5 \%$ of $E$. coli were isolated from feed samples in this study while in that of Chowdhuri et al. (2011) in Bangladesh, 57.1\% E. coli was found in feed samples. A total of $33.3 \%$ of the flies' samples collected at the cattle farms carried $E$. coli which can spread easily from or to the environment. Other factors that have been reported to be sources of $E$. coli included farm equipment, utensils, containers, carts and workers.

Table 1: Primers used to detect pathogenic E. coli.

\begin{tabular}{|c|c|c|c|c|c|}
\hline $\begin{array}{l}\text { Target/ E. coli } \\
\text { Type }\end{array}$ & Primer & Sequence (5' to $\left.3^{\prime}\right)$ & $\begin{array}{l}\text { Target } \\
\text { gene }\end{array}$ & $\begin{array}{l}\text { Size of PCR } \\
\text { amplicon (bp) }\end{array}$ & Reference \\
\hline ETEC & $\begin{array}{l}s t-\mathrm{F} \\
s t-\mathrm{R}\end{array}$ & $\begin{array}{l}\text { TCTTTCCCCTCTTTTAGTCAGTC } \\
\text { CCAGCACAGGCAGGATTAC }\end{array}$ & st & 170 & $\begin{array}{l}\text { Watterworth } \\
\text { et al. (2005) }\end{array}$ \\
\hline ETEC & $\begin{array}{l}I t-F \\
I t-R\end{array}$ & $\begin{array}{l}\text { TCTCTATGTGCACACGGAGC } \\
\text { CCATACTGATTGCCGCAAT }\end{array}$ & It & 322 & $\begin{array}{l}\text { Watterworth } \\
\text { et al. (2005) }\end{array}$ \\
\hline EIEC & $\begin{array}{l}l a l-F \\
l a l-R\end{array}$ & $\begin{array}{l}\text { TTTCTGGATGGTATGGTGAGG } \\
\text { CACGCTGGTTGTCAATAATGCT }\end{array}$ & lal & 390 & $\begin{array}{l}\text { Watterworth } \\
\text { et al. (2005) }\end{array}$ \\
\hline $\begin{array}{l}\text { EHEC/ } \\
\text { E. coli } 0157\end{array}$ & $\begin{array}{l}r f b O 157-F \\
r f b O 157-R\end{array}$ & $\begin{array}{l}\text { CGGACATCCATGTGATATGG } \\
\text { TTGCCTATGTACAGCTAATCC }\end{array}$ & $r f b O 157$ & 259 & $\begin{array}{l}\text { Chang et al } \\
(2013)\end{array}$ \\
\hline $\mathrm{EHEC/} \mathrm{H7}$ & $\begin{array}{l}\text { fliCH7-F } \\
\text { fliCH7-R }\end{array}$ & $\begin{array}{l}\text { GCGCTGTCGAGTTCTATCGAG } \\
\text { CAACGGTGACTTTATCGCCATTCC }\end{array}$ & $\mathrm{fliCH7}$ & 625 & $\begin{array}{l}\text { Chang et al } \\
(2013)\end{array}$ \\
\hline
\end{tabular}


Table 2: Proportion of $E$. coli isolates in cattle and farm environment.

\begin{tabular}{|c|c|c|c|c|c|}
\hline \multirow{2}{*}{ Farms } & \multicolumn{5}{|c|}{ Types of samples } \\
\hline & Faeces (cattle) & Feed & Floor of Stall & Flies & Water \\
\hline Farm 1 & $\begin{array}{l}0 / 12 \\
(0 \%)\end{array}$ & $\begin{array}{c}0 / 3 \\
(0 \%)\end{array}$ & $\begin{array}{c}0 / 3 \\
(0 \%)\end{array}$ & $\begin{array}{c}0 / 3 \\
(0 \%)\end{array}$ & $\begin{array}{c}0 / 3 \\
(0 \%)\end{array}$ \\
\hline Farm 2 & $\begin{array}{c}5 / 12 \\
(41.7 \%)\end{array}$ & $\begin{array}{c}1 / 3 \\
(33.34 \%)\end{array}$ & $\begin{array}{c}2 / 3 \\
(66.67 \%)\end{array}$ & $\begin{array}{c}2 / 3 \\
(66.67 \%)\end{array}$ & $\begin{array}{c}1 / 3 \\
(33.34 \%)\end{array}$ \\
\hline Farm 3 & $11 / 12(91.7 \%)$ & $\begin{array}{c}1 / 3 \\
(33.34 \%)\end{array}$ & $\begin{array}{c}2 / 3 \\
(66.67 \%)\end{array}$ & $\begin{array}{c}1 / 3 \\
(33.34 \%)\end{array}$ & $\begin{array}{c}3 / 3 \\
(100 \%)\end{array}$ \\
\hline Farm 4 & $11 / 12(91.7 \%)$ & $\begin{array}{c}0 / 3 \\
(0 \%)\end{array}$ & $\begin{array}{c}3 / 3 \\
(100 \%)\end{array}$ & $\begin{array}{c}0 / 3 \\
(0 \%)\end{array}$ & $\begin{array}{c}2 / 3 \\
(66.67 \%)\end{array}$ \\
\hline Farm 5 & $\begin{array}{l}6 / 12 \\
(50 \%)\end{array}$ & $\begin{array}{c}3 / 3 \\
(100 \%)\end{array}$ & $\begin{array}{c}2 / 3 \\
(66.67 \%)\end{array}$ & $\begin{array}{c}0 / 3 \\
(0 \%)\end{array}$ & $\begin{array}{c}1 / 3 \\
(33.34 \%)\end{array}$ \\
\hline Farm 6 & $\begin{array}{c}8 / 12 \\
(66.7 \%)\end{array}$ & $\begin{array}{c}2 / 3 \\
(66.67 \%)\end{array}$ & $\begin{array}{c}2 / 3 \\
(66.67 \%)\end{array}$ & $\begin{array}{c}2 / 3 \\
(66.67 \%)\end{array}$ & $\begin{array}{c}0 / 3 \\
(0 \%)\end{array}$ \\
\hline Farm 7 & $\begin{array}{c}6 / 12 \\
(50 \%)\end{array}$ & $\begin{array}{c}2 / 3 \\
(66.67 \%)\end{array}$ & $\begin{array}{c}1 / 3 \\
(33.34 \%)\end{array}$ & $\begin{array}{c}0 / 3 \\
(0 \%)\end{array}$ & $\begin{array}{c}2 / 3 \\
(66.67 \%)\end{array}$ \\
\hline Farm 8 & $\begin{array}{c}6 / 12 \\
(50 \%)\end{array}$ & $\begin{array}{c}0 / 3 \\
(0 \%)\end{array}$ & $\begin{array}{c}3 / 3 \\
(100 \%)\end{array}$ & $\begin{array}{c}3 / 3 \\
(100 \%)\end{array}$ & $\begin{array}{c}1 / 3 \\
(33.34 \%)\end{array}$ \\
\hline Total & $53 / 96(55.2 \%)$ & $\begin{array}{c}9 / 24 \\
(37.5 \%)\end{array}$ & $\begin{array}{c}15 / 24 \\
(62.5 \%)\end{array}$ & $\begin{array}{c}8 / 24 \\
(33.3 \%)\end{array}$ & $\begin{array}{c}10 / 24 \\
(41.6 \%)\end{array}$ \\
\hline
\end{tabular}

The highest prevalence of $E$. coli was observed in Farm 3 at $75 \%$ (18/24). During my visit to the farms, in comparison to other farms, Farm 3 was comparatively less clean, faeces were not regularly removed from the floor of stall, cattle were not regularly cleaned, personal hygiene of farm workers were also compromised and garbage heaps were observed nearby the farm. The above reasons may have contributed in high prevalence of $E$. coli in Farm 3.

Escherichia coli may be frequently found on raw food due to contamination by faeces, water and flies; of public health concern is the pathogenic $E$. coli in food (Costa et al., 2008). E. coli were isolated from $33.3 \%$ of 30 milk samples collected from cattle in five dairy cattle farms and ranged from $0 \%$ in two farms, $33.3 \%, 50 \%$ and $83.3 \%$ in three farms. Almost similar prevalence (31.6\%) was observed among raw milk samples in a study by Nanu et al. (2007) in India while higher prevalence of $E$. coli among raw milk samples was observed in a study by Chye et al. (2004) in Malaysia at 65\%. The factors involved in contamination of milk with $E$. coli may include the use of contaminated utensils, use of contaminated water for cleaning udder, contamination of milk with faeces, improper storage conditions, unhygienic milking equipments and dirty hands (Bagré et al., 2014).
Escherichia coli and other species in the Enterobacteriaceae group are of public health concern in the production of raw and processed meat worldwide (Adetunji \& Odetokun, 2011). During slaughtering and dressing including evisceration, the carcass can be contaminated with $E$. coli through inappropriate and unhygienic practices, contaminated water, equipment, processing and storage environments at the abattoirs (Karch et al., 2005). In the present study, $10 \%$ of beef sampled were contaminated with $E$. coli. The rate of contamination on beef ranged from $0 \%$ in four markets, $5.5 \%, 25 \%$ and $33.3 \%$ in three markets. Similar results were observed in a study by Hajian et al. (2011) in cattle beef in Iran who reported E. coli at $8.9 \%$ while Tanih et al. (2015) in South Africa found $67.5 \%$ of beef in abattoirs were contaminated with $E$. coli. The significant risk factors involved in contamination of beef in the market with $E$. coli included contaminated carcasses in the abattoirs, carcasses contaminated during handling and transport, contaminated clothing and hands of personnel and the physical facilities including knives, cutting boards, tables and water used for cleaning and washing at the markets (Mohammed et al., 2014). 


\section{Latex agglutination test for identification of $E$. coli 0157}

Among the $E$. coli isolates which were subjected to latex agglutination test for identification of $E$. coli O157, 38 of $E$. coli isolated in faeces, feed, floor of stall, flies, water and milk were positive for presumptive $E$. coli $\mathrm{O} 157$ while none of the $E$. coli isolates from beef were positive. The occurrence of $E$. coli $\mathrm{O} 157$ in cattle faeces, farm environment, milk and beef was $34.2 \%$ (Table 3 ). Almost similar results were reported in a study by Omisakin et al. (2003) in faecal samples from the abattoirs in United Kingdom at $40.4 \%$ while comparatively low prevalence at $0.68 \%$ E. coli 0157 was recorded in a study by Onwumere (2010) on floors of slaughterhouse, slabs, meat and water samples in Nigeria. Seasonal variation in the prevalence of $E$. coli 0157 ranged from $4.8 \%$ during winter and $38 \%$ in spring was previously reported (Chapman et al., 1997; Heuvelink et al., 1998a; Gansheroff and O'Brien, 2000). These differences may be influenced by geographical location, season, stressful environmental condition, diet, and population density (Clarke et al., 1989; Kudva et al., 1996). A prevalence of $25 \%$ E. coli 0157 in feed samples was observed in beef cattle in a study by Sanderson et al. (2006). In contrast to the current study very low level of prevalence of $E$. coli 0157 was observed in feed samples from feed bunks reported by Van Donkersgoed et al. (2001) at 1.7\%, in barley feed for cattle at $2.4 \%$ and corn feed for cattle at $1.3 \%$ in a study by Berg et al. (2004) in Canada. Hancock et al. (1998) reported $3.1 \%$ E. coli 0157 were isolated from feedlots and in dairy farms in United States. In another study by LeJeune et al. (2001) 1.3\% E. coli 0157 were isolated from water troughs in dairy cattle operations. Among beef samples, Beutin (1999) in Germany, observed $0.8 \%$ E. coli 0157 while $0.7 \%$ was observed by Tutenel et al. (2002) in Poland.

\section{Detection of $E$. coli 0157:H7 by PCR assay}

All the $E$. coli isolates which were subjected to PCR for the detection of $r f b O 157$ (EHEC) genes were negative; however, $3.6 \%$ among all $E$. coli isolates and $10.5 \%$ among presumptive E. coli 0157 isolates showed the presence of fliCH7 (H7) genes at $625 \mathrm{bp}$ (Figure 1). When the $E$. coli isolates were subjected to m-PCR for the detection of other pathogenic $E$. coli by observing the presence of st and It (ETEC) and lal (EIEC) genes, they were found negative. Almost similar observations were made by Apun et al. (2011), in which prevalence of $E$. coli was observed in rodents $(43 \%)$, birds $(18 \%)$ and bats (11\%), however fliCH7 gene was detected in 23 (3.37\%) while none of the isolate carry slt-I, slt-II, rfbE genes. Thus it was suggested that bats, birds and rodents do not serve as a reservoir for E. coli O157:H7 in Sarawak Malaysia. The cattle, farm environment, milk and beef sampled were negative for pathogenic $E$. coli and in particular $E$. coli O157. However, the four isolates positive for $\mathrm{fliCH} 7$ genes could possibly belong to other $E$. coli serotypes (such as O26, $\mathrm{O} 103$ and O111) which may have the potential to cause diseases. The big difference in PCR and latex agglutination test results is due to the results of latex agglutination tests being interpreted positive as per the manufacturer instructions which includes the positive results as appearance of granules only in test reagent and more granules appearance in control reagent in comparison with test reagent while if the granules appeared only in control reagent then the results would be considered uninterpreted. According to Borczyk et al. $(1987,1990)$, cross reaction may occur in latex test due to the shared antigen of certain strains of Escherichia hermanii and E. coli O157.

The differences in the occurrence of $E$. coli in beef in this study to others may be due to different samples, isolation techniques, geographical locations or due to the processing and retailing conditions (Padhye and Doyle, 1992; Heuvelink et al., 1998b; Zhao et al., 2001). From this study, the occurrence of $E$. coli in the beef in wet markets were different among markets may be because the hygienic measures practiced in the wet markets were different.

The presence of birds and flies in and around the farms, the use of contaminated water and inappropriate practices of the workers in the farm may contribute in active transmission of the pathogens (Hancock et al., 1998; Coia el al., 2001; Scott et al., 2003; Wasteson et al., 2005).

The use of contaminated water for cleaning udder, contamination of milk with faeces, contaminated milking equipments and utensils and dirty milking hands may contribute in transmission of the organism in the milk (Chye et al., 2004).

Table 3: Proportion of E. coli O157 among E. coli isolates.

\begin{tabular}{cccc}
\hline Sample Type & Total number of E. coli isolates & Latex agglutination positive for E. coli O157 & $\begin{array}{c}\text { Occurrence of } \\
\text { E. coli O157 (\%) }\end{array}$ \\
\hline Faeces/Cattle & 53 & 23 & $43.3 \%$ \\
Feed & 9 & 2 & $22.2 \%$ \\
Floor of stall & 15 & 6 & $40 \%$ \\
Flies & 8 & 1 & $12.5 \%$ \\
Water & 10 & 4 & $40 \%$ \\
Milk & 10 & 2 & $20 \%$ \\
Beef & 6 & 0 & $0 \%$ \\
\hline Total & 111 & 38 & $34.2 \%$ \\
\hline
\end{tabular}




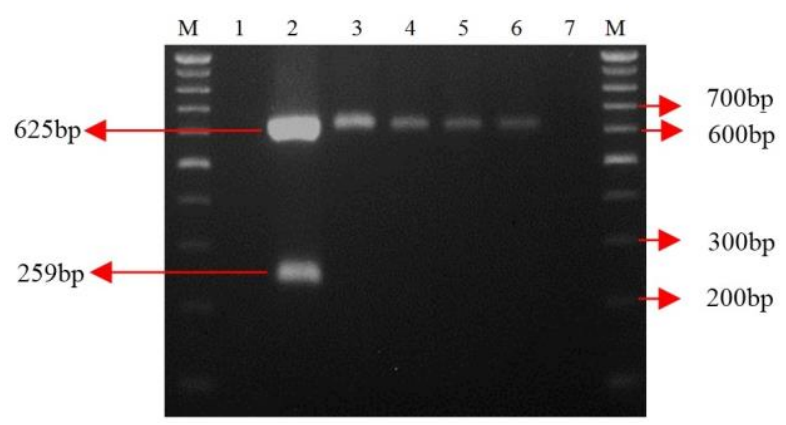

Lane M: marker 100 bp ladder, Lane 1: negative control, Lane 2: positive control ( $\mathrm{rfbO} 157$ \& fliCH7), Lane 3 to 6: H7 positive, Lane 7: negative control, Lane M: marker 100 bp ladder.

Figure 1: Representative PCR assay for detection of somatic $E$. coli $\mathrm{O} 157$ and $\mathrm{H} 7$ flagella of $E$. coli isolates.

Beef could have become contaminated with $E$. coli in the intestinal content, carcass in contact with faeces, contaminated water and equipment used during dressing (McEvoy et al., 2003). Beef may also become contaminated because of improper handling and cutting at the markets (Zhao et al., 2001). Poor or unhygienic measures in markets and equipment comprises protective equipment, workers hygiene, lack of using gloves, hygiene measures or cleanliness of stalls and display counters, contaminated storage, containers, transporting facilities and chilling facilities (Elder et al., 2000, Adesiji et al., 2011). Raw beef is highly contaminated with $E$. coli may indicate poor hygienic measures but may possibly carry other zoonotic pathogens.

\section{CONCLUSION}

There is a high occurrence of $E$. coli in cattle and farm environment. Beef in the markets and milk from cows were also highly contaminated. The high occurrence of $E$. coli in the faeces may contaminate environment as well may cross-contaminate other animals in the farms. Farm management practice, market and stall conditions, environmental factors and workers personal hygiene plays an important role in microbial contaminations. It is shown in this study that pathogenic $E$. coli were not present in the cattle and farms as well on beef in the markets that were sampled. This study may serve as a template to investigate the role of farm and environmental factors in contamination of $E$. coli and other microbes relevant to food safety.

\section{ACKNOWLEDGEMENT}

Special thanks to Prof. Son Radu of Microbiology Lab, Faculty of Food Sciences and Technology, UPM for providing positive control for my research work.

\section{REFERENCES}

Adetunji, V. O. and Odetokun, I. A. (2011). Bacterial hazards and critical control points in goat processing at a typical tropical abattoir in Ibadan, Nigeria. International Journal of Animal and Veterinary Advances 3, 349-354.

Adesiji, Y. O., Alli, O. T., Adekanle, M. A. and Jolayemi, J. B. (2011). Prevalence of Arcobacter, Escherichia coli, Staphylococcus aureus and Salmonella species in retail raw chicken, pork, beef and goat meat in Osogbo, Nigeria. Sierra Leone Journal of Biomedical Research 3(1), 8-12.

Adzitey, F., Huda, N. and Rusul, G. (2010). Prevalence of Escherichia coli in duck intestines, faeces, soil and Wash Water samples in Penang, Malaysia. Proceedings of the 4th International Conference Postgraduate Education: Globalisation and Liberalisation of Postgraduate Education, Nov. pp. 26-28.

Allocati, N., Masulli, M., Alexeyev, M. F., and Di Ilio, C. (2013). Escherichia coli in Europe: An overview. International Journal of Environmental Research and Public Health 10(12), 6235-6254.

Apun, K., Kho, K., Chong, Y., Hashimatul, F., Abdullah, M., Rahman, M. and Samuel, L. (2011). Detection of Escherichia coli O157: H7 in wildlife from disturbed habitats in Sarawak, Malaysia. Research Journal of Microbiology 6(2), 132.

Awadallah, M. A., Merwad, A. M. and Mohamed, R. E. (2013). Prevalence of zoonotic Escherichia coli and Salmonella in wild birds and humans in Egypt with emphasis on RAPD-PCR fingerprinting of $E$. coli. Global Veterinaria 11, 781-788.

Bagré, T. S., Kagambèga, A., Bawa, H. I., Tchamba, G. B., Dembélé, R. E., Zongo, C., Savadogo, A., Aggad, H., Traoré, A. S. and Barro, N. (2014). Antibiotic susceptibility of Escherichia coli and Salmonella strains isolated from raw and curds milk consumed in Ouagadougou and Ziniar, Burkina Faso. African Journal of Microbiology Research 8(10), 1012-1016.

Beauchamp, C. S. and Sofos, J. N. (2010). Diarrheagenic Escherichia coli. In:Pathogens and Toxins in Foods. American Society of Microbiology Press. Washington DC. pp. 71-94.

Berg, J., McAllister, T., Bach, S., Stilborn, R., Hancock, D. and LeJeune, J. (2004). Escherichia coli 0157: $\mathrm{H} 7$ excretion by commercial feedlot cattle fed either barley-or corn-based finishing diets. Journal of Food Protection, 67(4), 666-671.

Beutin, L. (1999). Escherichia coli $O 157$ and other types of verocytotoxigenic $E$. coli (VTEC) isolated from humans, animals and food in Germany. CABI Publishing Wallingford. United Kingdom. pp. 121-145.

Borczyk, A. A., N. Harnett, M. Lombos, and H. Lior. (1990). False positive identification of Escherichia coli 0157 by commercial latex agglutination test. Lancet 336, 946-947. 
Borczyk, A. A., Lior, H., and Ciebin, B. (1987). False positive identifications of Escherichia coli 0157 in foods. International Journal of Food Microbiology 4(4), 347-349.

Chang, W. S., Afsah-Hejri, L., Rukayadi, Y., Khatib, A., Lye, Y. L., Loo, Y. Y., Shahril, N. M., Puspanadan, S., Kuan, C. H., Goh, S. G. and John, Y. H. T. (2013). Quantification of Escherichia coli O157: $\mathrm{H} 7$ in organic vegetables and chickens. International Food Research Journal 20(2), 1023-1029.

Chapman, P., Siddons, C., Malo, A. C. and Harkin, M. (1997). A 1-year study of Escherichia coli 0157 in cattle, sheep, pigs and poultry. Epidemiology and Infection 119(02), 245-250.

Chowdhuri, A., Iqbal, A., Giasuddin, M. and Bhuiyan, A. (2011). Study on isolation and identification of Salmonella and Escherichia coli from different poultry feeds of Savar region of Dhaka, Bangladesh. Journal of Scientific Research 3(2), 403-411.

Chye, F. Y., Abdullah, A., and Ayob, M. K. (2004). Bacteriological quality and safety of raw milk in Malaysia. Food Microbiology 21(5), 535-541.

Clarke, R., McEwen, S., Gannon, V., Lior, H., and Gyles, C. (1989). Isolation of verocytotoxin-producing Escherichia coli from milk filters in south-western Ontario. Epidemiology and Infection 102(02), 253260.

Coia, J. E., Johnston, Y., Steers, N. J., and Hanson, M. F. (2001). A survey of the prevalence of Escherichia coli $\mathrm{O} 157$ in raw meats, raw cow's milk and raw-milk cheeses in south-east Scotland. International Journal of Food Microbiology 66(1), 63-69.

Cooley, M., Carychao, D., Crawford-Miksza, L., Jay, M. T., Myers, C., Rose, C., Keys, C., Farrar, J. and Mandrell, R. E. (2007). Incidence and tracking of Escherichia coli 0157: H7 in a major produce production region in California. PloS One 2(11), e1159.

Costa, D., Poeta, P., Sáenz, Y., Coelho, A.C., Matos, M., Vinué, L., Rodrigues, J. and Torres, C. (2008). Prevalence of antimicrobial resistance and resistance genes in faecal Escherichia coli isolates recovered from healthy pets. Veterinary Microbiology 127(1), 97105.

Croxen, M. A., and Finlay, B. B. (2010). Molecular mechanisms of Escherichia coli pathogenicity. Nature Reviews Microbiology 8(1), 26-38.

Dodd, C. C., Sanderson, M. W., Sargeant, J. M., Nagaraja, T., Oberst, R. D., Smith, R. A. and Griffin, D. D. (2003). Prevalence of Escherichia coli O157 in cattle feeds in Midwestern feedlots. Applied and Environmental Microbiology 69(9), 5243-5247.

Elder, R. O., Keen, J. E., Siragusa, G. R., BarkocyGallagher, G. A., Koohmaraie, M., and Laegreid, W. W. (2000). Correlation of enterohemorrhagic Escherichia coli 0157 prevalence in feces, hides, and carcasses of beef cattle during processing. Proceedings of the National Academy of Sciences 97(7), 2999-3003.
Fluckey, W. M., Loneragan, G. H., Warner, R. and Brashears, M. M. (2007). Antimicrobial drug resistance of Salmonella and Escherichia coli isolates from cattle feces, hides, and carcasses. Journal of Food Protection 70(3), 551-556.

Gansheroff, L. J., and O'Brien, A. D. (2000). Escherichia coli O157: $\mathrm{H} 7$ in beef cattle presented for slaughter in the US: higher prevalence rates than previously estimated. Proceedings of the National Academy of Sciences. pp. 2959-2961.

Hajian, S., Rahimi, E., and Mommtaz, H. (2011). A 3year study of Escherichia coli O157: $\mathrm{H} 7$ in cattle, camel, sheep, goat, chicken and beef minced meat. Proceedings of the International Conference on Food Engineering and Biotechnology. (IPCBEE'11).

Hancock, D. D., Besser, T. E., Rice, D. H., Ebel, E. D., Herriott, D. E., and Carpenter, L. V. (1998). Multiple sources of Escherichia coli 0157 in feedlots and dairy farms in the northwestern USA. Preventive Veterinary Medicine 35(1), 11-19.

Heuvelink, A.E., Van Den Biggelaar, F.L.A.M., Zwartkruis-Nahuis, J.T.M., Herbes, R.G., Huyben, R., Nagelkerke, N., Melchers, W.J.G., Monnens, L.A.H. and De Boer, E. (1998a). Occurrence of verocytotoxin-producing Escherichia coli 0157 on Dutch dairy farms. Journal of Clinical Microbiology 36(12), 3480-3487.

Heuvelink, A. E., Van Den Biggelaar, F. L. A. M., De Boer, E., Herbes, R. G., Melchers, W. J. G., Huis, J. H. J., and Monnens, L. A. H. (1998b). Isolation and characterization of verocytotoxin-producing Escherichia coli 0157 strains from Dutch cattle and sheep. Journal of Clinical Microbiology 36(4), 878882.

Hossain, M., Rahman, M., Nahar, A., Khair, A., and Alam, M. (2014). Isolation and identification of diarrheagenic Escherichia coli causing colibacillosis in calf in selective areas of Bangladesh. Bangladesh Journal of Veterinary Medicine 11(2), 145-149.

Jafari, A., Aslani, M. and Bouzari, S. (2012). Escherichia coli: A brief review of diarrheagenic pathotypes and their role in diarrheal diseases in Iran. Iranian Journal of Microbiology 4(3), 102-117.

Jiang, X., Morgan, J. and Doyle, M. P. (2002). Fate of Escherichia coli 0157: H7 in manure-amended soil. Applied and Environmental Microbiology 68(5), 26052609.

Jianghong Meng, C. M. S. (2007). Escherichia coli. In: Foodborne diseases. Humana Press. pp. 1-25).

Karch, H., Tarr, P. I., and Bielaszewska, M. (2005). Enterohaemorrhagic Escherichia coli in human medicine. International Journal of Medical Microbiology 295(6), 405-418.

Khanjar, A. and Alwan, M. (2014). Genotypic study of Escherichia coli 0157: $\mathrm{H} 7$ isolated from stool samples of humans and cattle. International Journal of Advanced Research 2(6), 204-212.

Kudva, I. T., Hatfield, P. G. and Hovde, C. J. (1996). Escherichia coli O157: H7 in microbial flora of sheep. Journal of Clinical Microbiology 34(2), 431-433. 
LeJeune, J., Besser, T., Merrill, N., Rice, D. and Hancock, D. (2001). Livestock drinking water microbiology and the factors influencing the quality of drinking water offered to cattle. Journal of Dairy Science 84(8), 1856-1862.

Mainda, G., Bessell, P. R., Muma, J. B., McAteer, S. P., Chase-Topping, M. E., Gibbons, J., Stevens, M. P., Gally, D. L. and Barend, M. (2015). Prevalence and patterns of antimicrobial resistance among Escherichia coli isolated from Zambian dairy cattle across different production systems. Scientific Reports 5, 12439.

Martinez-Medina, M. and Garcia-Gil, L. J. (2014). Escherichia coli in chronic inflammatory bowel diseases: An update on adherent invasive Escherichia coli pathogenicity. World Journal of Gastrointestinal Pathophysiology 5(3), 213.

McEvoy, J. M., Doherty, A. M., Sheridan, J. J., Thomson-Carter, F. M., Garvey, P., McGuire, L., Blair, I. S. and McDowell, D. A. (2003). The prevalence and spread of Escherichia coli O157: H7 at a commercial beef abattoir. Journal of Applied Microbiology 95(2), 256-266.

Mohammed, O., Shimelis, D., Admasu, P. and Feyera, T. (2014). Prevalence and antimicrobial susceptibility pattern of $E$. coli isolates from raw meat samples obtained from abattoirs in Dire Dawa City, International Journal of Microbiological Research 5(1), 35-39.

Nanu, E., Latha, C., Sunil, B., Prejit, M. T. and Menon, K. V. (2007). Quality assurance and public health safety of raw milk at the production point. American Journal of Food Technology 2(3), 145-152.

Nataro, J. P. and Kaper, J. B. (1998). Diarrheagenic Escherichia coli. Clinical Microbiology Reviews 11(1), 142-201.

Omisakin, F., MacRae, M., Ogden, I. and Strachan, N. (2003). Concentration and prevalence of Escherichia coli $\mathrm{O} 157$ in cattle feces at slaughter. Applied and Environmental Microbiology 69(5), 2444-2447.

Onwumere, O. S. (2010). Isolation and phenotyptic characterisation of E. coli $\mathrm{O} 157$ and Salmonella spp in a slaughter house and meat sale tables at Nsukka market, Enugu State. MSc. Thesis. University of Nigeria, Nsukka.

Padhye, N. V. and Doyle, M. P. (1992). Escherichia coli O157: H7: epidemiology, pathogenesis, and methods for detection in food. Journal of Food Protection 55(7), 555-565.

Quinn, P., Markey, B., Carter, M., Donnelly, W. and Leonard, F. (2002). Veterinary Microbiology and Microbial Diseases. Lowa State University Press Blackwell Science. Oxford London. pp. 1-648.

Riley, L. W., Remis, R. S., Helgerson, S. D., McGee, H. B., Wells, J. G., Davis, B. R., Hebert, R. J., Olcott, E. S., Johnson, L. M., Hargrett, N. T. and Blake, P. A. (1983). Hemorrhagic colitis associated with a rare Escherichia coli serotype. New England Journal of Medicine 308(12), 681-685.
Šafařiková, M. and Šafařik, I. (2001). Immunomagnetic separation of Escherichia coli O26, O111 and O157 from vegetables. Letters in Applied Microbiology 33(1), 36-39.

Sanderson, M. W., Sargeant, J. M., Shi, X., Nagaraja, T., Zurek, L. and Alam, M. (2006). Longitudinal emergence and distribution of Escherichia coli $\mathrm{O} 157$ genotypes in a beef feedlot. Applied and Environmental Microbiology 72(12), 7614-7619.

Scott, T. M., Parveen, S., Portier, K. M., Rose, J. B., Tamplin, M. L., Farrah, S. R., Koo, A. and Lukasik, J. (2003). Geographical variation in ribotype profiles of Escherichia coli isolates from humans, swine, poultry, beef, and dairy cattle in Florida. Applied and Environmental Microbiology 69(2), 1089-1092.

Tanih, N. F., Sekwadi, E., Ndip, R. N., and Bessong, P. O. (2015). Detection of pathogenic Escherichia coli and Staphylococcus aureus from cattle and pigs slaughtered in Abattoirs in Vhembe District, South Africa. The Scientific World Journal 2015(195972), 8.

Tutenel, A.V., Pierard, D., Uradzinski, J., Jozwik, E., Pastuszczak, M., Van Hende, J., Uyttendaele, M., Debevere, J., Cheasty, T., Van Hoof, J. and De Zutter, L. (2002). Isolation and characterization of enterohaemorrhagic Escherichia coli O157: H7 from cattle in Belgium and Poland. Epidemiology and Infection 129(01), 41-47.

Van Donkersgoed, J., Berg, J., Potter, A., Hancock, D., Besser, T., Rice, D., LeJeune, J. and Klashinsky, S. (2001). Environmental sources and transmission of Escherichia coli 0157 in feedlot cattle. The Canadian Veterinary Journal 42(9), 714.

Wani, S., Bhat, M., Samanta, I., Nishikawa, Y. and Buchh, A. (2003). Isolation and characterization of Shiga toxin-producing Escherichia coli (STEC) and enteropathogenic Escherichia coli (EPEC) from calves and lambs with diarrhoea in India. Letters in Applied Microbiology 37(2), 121-126.

Watterworth, L., Topp, E., Schraft, H. and Leung, K. T. (2005). Multiplex PCR-DNA probe assay for the detection of pathogenic Escherichia coli. Journal of Microbiological Methods 60(1), 93-105.

Wasteson, Y., Johannessen, G. S., Bruheim, T., Urdahl, A. M., O'sullivan, K. and Rørvik, L. M. (2005). Fluctuations in the occurrence of Escherichia coli O157: H7 on a Norwegian farm. Letters in Applied Microbiology 40(5), 373-377.

Wong, T. L., Hollis, L., Cornelius, A., Nicol, C., Cook, R. and Hudson, J. A. (2007). Prevalence, numbers, and subtypes of Campylobacter jejuni and Campylobacter coli in uncooked retail meat samples. Journal of Food Protection 70(3), 566-573.

Zhao, C., Ge, B., De Villena, J., Sudler, R., Yeh, E., Zhao, S., White, D.G., Wagner, D. and Meng, J. (2001). Prevalence of Campylobacter spp., Escherichia coli, and Salmonella serovars in retail chicken, turkey, pork, and beef from the Greater Washington, DC, area. Applied and Environmental Microbiology 67(12), 5431-5436. 